\title{
Levels of Cadmium and Lead in Water, Sediments and Selected Fish Species in Mombasa, Kenya
}

\author{
Benjamin M. Mwashote \\ Kenya Marine and Fisheries Research Institute, P. O. Box 81651 Mombasa, Kenya
}

Key words: heavy metals, cadmium, lead, water, sediment, fish, Kenya coast

\begin{abstract}
Flame absorption spectrophotometry was used to investigate the concentration and distribution of cadmium and lead in water, sediments and selected fish species in Makupa and Tudor creeks in Mombasa, Kenya between May 1997 and March 1998. The results were compared with those obtained in relatively less anthropogenically influenced areas along the Kenyan coast.

The mean concentrations for $\mathrm{Pb}$ ranged from not detectable (nd) to $0.012 \mathrm{mg} / \mathrm{l}, 0.2$ to 58.0 $\mathrm{mg} / \mathrm{kg}$ and nd to $59.3 \mathrm{mg} / \mathrm{kg}$ in water, sediment and fish samples respectively. Cadmium concentrations in water were generally below detection limits, while in sediment and fish samples, they ranged from nd to $1.0 \mathrm{mg} / \mathrm{kg}$ and nd to $3.7 \mathrm{mg} / \mathrm{kg}$ respectively. Overall, $\mathrm{Pb}$ and $\mathrm{Cd}$ concentrations were low in the water column of Makupa and Tudor creeks, with a few incidents of elevated levels in sediments and some fish species, especially during the rainy season. Makupa creek had the higher levels overall. The levels of $\mathrm{Pb}$ and $\mathrm{Cd}$ in most of the fish species analysed were generally within acceptable limits by FAO standards.
\end{abstract}

\section{INTRODUCTION}

At low levels, some heavy metals, such as copper or cobalt, are essential for enzymatic activity, acting as enzyme inhibitors at higher concentrations. Other metals, such as cadmium and lead, have no known essential role in living organisms, and are toxic at even low concentrations (Bryan, 1976).

The pollution of marine ecosystems by heavy metals is a worldwide problem (Bryan, 1976; Ober et al., 1987), and the situation is aggravated by the ability of these ecosystems to concentrate and accumulate some metals within food chains (Wattling, 1983). Marine organisms, particularly filter feeders, can take up these metals through their digestive systems, thus increasing the potential for their entry into the human food chain (Forstner, 1990). It is therefore important to continuously monitor the levels of heavy metals in aquatic environments.
In recent years, the need for a better understanding of heavy metal concentration and dispersion patterns in coastal environments has been highlighted following the discovery of high levels of toxic heavy metals (particularly cadmium and lead) in seafood and other living organisms (McConchie et al., 1988; Onyari, 1985; Oteko, 1987).

In order to have impact on aquatic organisms, metals must occur in a biologically available form (Waldichuk, 1985). The bioavailability of sediment-bound trace metals is dependent not only on the total metal concentration, but also on the strength of the association between the metal and sediment compounds. Jenne \& Luoma (1977) showed that metals bound to different substrates of a given sediment are incorporated at different rates by benthic organisms. Metals bound to biogenic carbonate and organic matter are much more available than metals strongly bound to other sediment compounds, such as iron oxides and 
sulphides (Lacerda et al., 1988; Lacerda, 1990).

The proportion of exchangeable metals in a given sediment is also dependent on other environmental variables. These include the physical and chemical characteristics of both the sediment pore water and the overlying waters. Changes in $\mathrm{pH}$ and electrode potential $\left(\mathrm{E}_{\mathrm{h}}\right)$ can mobilise heavy metals from sediments to the water column, either by dissolving unstable metal compounds, precipitating heavy metals by favouring the absorption onto suspended particle surfaces, or through the formation of insoluble metal sulphides (Souza et al., 1986; Mohan, 1997; Kim et al., 1998).

The Kenyan coastal city of Mombasa and its environs has in recent times seen considerable industrial and population development. The rapid expansion of the region is mainly thanks to the presence of Kilindini harbour, the principal port which serves a number of landlocked countries within the region, as well as a thriving tourism industry (GoK, 1988). It is feared that the anthropogenic influences associated with these developments may lead to both direct and indirect degradation of the marine environment, including increases in concentrations of heavy metals such as cadmium and lead.

This study evaluates the distribution of cadmium and lead in water, sediment and some common edible fish species in Tudor and Makupa creeks in Mombasa-both areas of high anthropogenic influence-and compares these to values found in other areas with lower anthropogenic pressure.

\section{MATERIALS AND METHODS}

\section{Study area}

The main study areas were Makupa and Tudor creeks (Fig. 1). The two creeks lie within $4^{\circ} 00^{\prime}$ and $4^{\circ} 04^{\prime} \mathrm{S}$ and $39^{\circ} 36^{\prime}$ and $39^{\circ} 42^{\prime}$ E. Makupa creek forms part of a larger creek system in which the port of Mombasa (Kilindini) is located, to the west of Mombasa Island. Tudor creek is on the eastern side of Mombasa Island and is separated from Makupa creek by a narrow strip of landfill, the Makupa causeway.

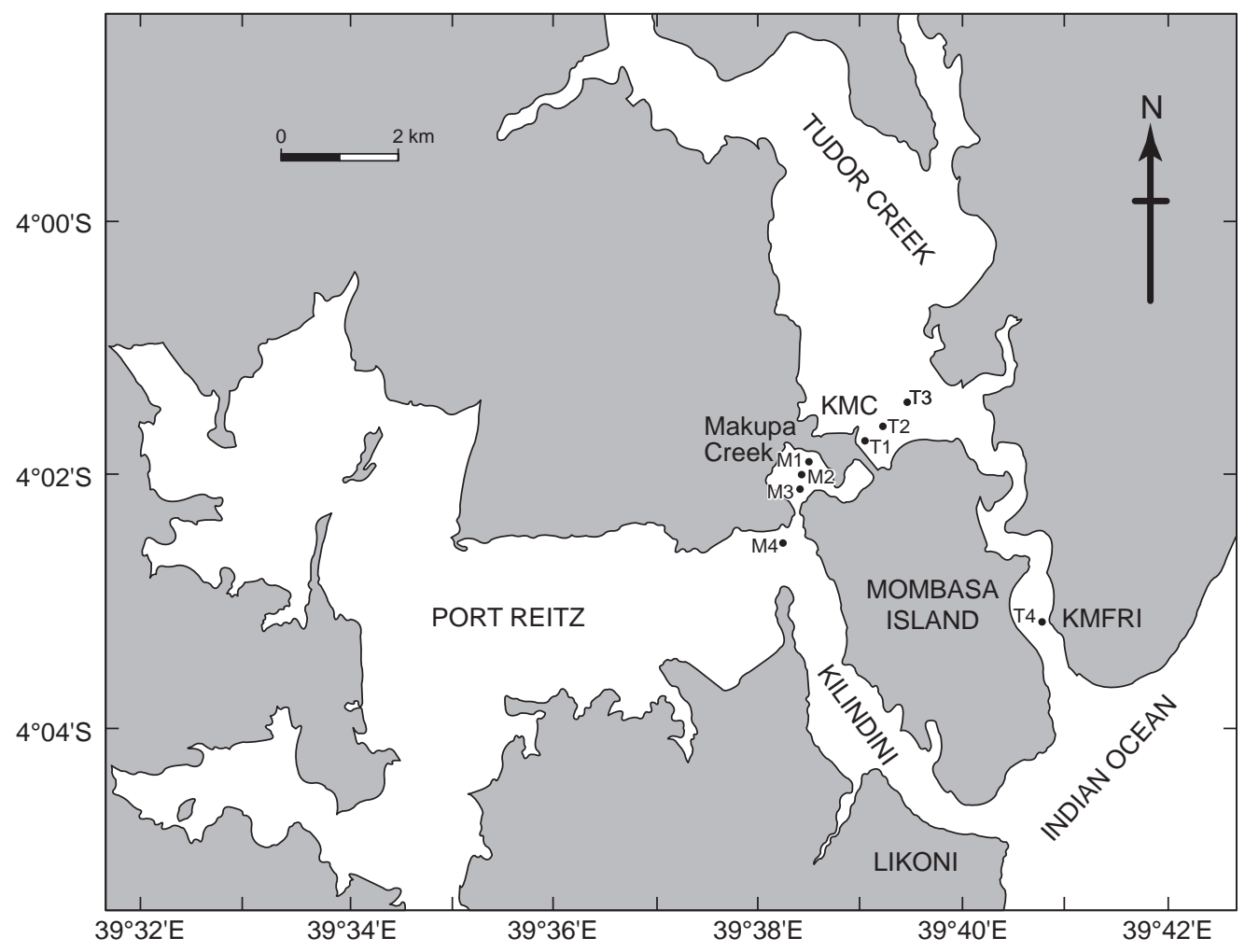

Fig. 1. Map of the study area showing sampling stations (M1-M4 and T1 - T4) 
In both the creeks, the sampled areas were relatively shallow $(<10 \mathrm{~m})$. Four sampling stations were chosen in each creek: M1, M2, M3 and M4 at Makupa Creek and T1, T2, T3 and T4 at Tudor Creek. The main characterising features of interest around the creeks include the Kilindini port and the Mombasa Municipal refuse dumpsite (Kibarani), both of which are found in the vicinity of the Makupa creek sampling stations and the Kenya Meat Commission (KMC) beef factory located within the vicinity of the Tudor creek sampling stations.

In addition to the eight stations within the study area (Fig. 1), six other stations outside the MakupaTudor creek systems were sampled for comparison. These six were located within Gazi bay (CGaB), Mkurumuji river (CMkR), Kidogoweni river (CKiR), Mida creek (CMiC), Kombeni river (CKoR) and Mwache river (CMwR). Their coordinates are respectively, $\left(4^{\circ} 25^{\prime} \mathrm{S}, 39^{\circ} 30^{\prime} \mathrm{E}\right),\left(4^{\circ} 26^{\prime} \mathrm{S}, 39^{\circ}\right.$ $\left.29^{\prime} \mathrm{E}\right),\left(4^{\circ} 24^{\prime} \mathrm{S}, 39^{\circ} 30^{\prime} \mathrm{E}\right),\left(3^{\circ} 20^{\prime} \mathrm{S}, 39^{\circ} 58^{\prime} \mathrm{E}\right)$, $\left(4^{\circ} 00^{\prime} \mathrm{S}, 39^{\circ} 31^{\prime} \mathrm{E}\right)$ and $\left(3^{\circ} 56^{\prime} \mathrm{S}, 39^{\circ} 40^{\prime} \mathrm{E}\right)$.

\section{Sampling and analysis}

Sampling was done during both the wet and dry seasons of 1997 and 1998. The wet months were May, June, November, December and January while the dry months were August, September and March. There was a slight modification in the sequence of months that normally constitute the two seasons due to the influence of the unprecedented El Niño phenomenon during the latter part of the sampling period.

All glassware and apparatus used in analytical work were soaked in detergent for $24 \mathrm{~h}$, rinsed with water, soaked in $10 \%$ nitric acid for $24 \mathrm{~h}$, rinsed with distilled deionised water then kept in an oven at $110^{\circ} \mathrm{C}$ until needed. The chemicals and reagents used were of analytical grade or equivalent and pre-tested for possible heavy metal contamination. Distilled, de-ionised water was used for preparing working solutions and all analytical work. All water, sediment and fish samples were analysed in duplicate for total cadmium and lead by flame atomic absorption spectrophotometry (AAS, Varian model spectr AA-10). On average, sample sizes were $n \geq 10$ and $n \geq 6$ respectively with respect to water and sediment samples. Twenty different fish species were sampled but due to the inconsistent catches, the sample sizes were highly variable and generally smaller than those of the water and sediment samples.

Water samples were analysed according to the modified method of Brewer et al. (1969) as described in FAO (1975). In this method, $100 \mathrm{ml}$ of water were filtered $(0.45 \mu \mathrm{m}$ micropore filter $)$ into a beaker. The $\mathrm{pH}$ was adjusted to between 2.2 to 2.8 using $0.5 \mathrm{M}$ hydrochloric acid or $0.5 \mathrm{M}$ sodium hydroxide solutions as appropriate added dropwise with stirring, before transferring the mixture to a $200 \mathrm{ml}$ separation funnel. Five millilitres $(5 \mathrm{ml})$ of the extractant solution $(1 \%$ ammonium pyrrolidine dithiocarbamate, APDC) and $10 \mathrm{ml}$ of methyl isobutyl ketone (MIBK) were added. The mixture was then shaken for $2 \mathrm{~min}$. and then left for $30 \mathrm{~min}$. to allow the layers to separate. The lower aqueous layer was run off leaving behind the organic layer. The organic layer was then run into a $10 \mathrm{ml}$ volumetric flask and made up to the mark with pure MIBK. The MIBK layer was then aspirated into the AAS for cadmium and lead determination. Standards and blanks were treated similarly.

Sediment samples were analysed according to the method described by Peerzada and Rohoza (1989). Using this procedure, samples were dried in an oven at $110^{\circ} \mathrm{C}$ for $6 \mathrm{hr}$ and then ground in an agate mortar. One gramme $(1.0 \mathrm{~g})$ of homogenised sample, sieved through a $1-\mathrm{mm}$ sieve, was weighed and $3 \mathrm{ml}$ of concentrated nitric acid added, then evaporated to semi-dryness at $150{ }^{\circ} \mathrm{C}$. The residue was dissolved in $5 \mathrm{ml}$ perchloric acid and the mixture again evaporated to semi-dryness. The residue was finally dissolved in $3 \%$ hydrochloric acid (v/v) and its volume made up to the mark in a 50-ml volumetric flask. Blank digestions were treated in the same way.

The fish species were randomly collected with the help of local fishermen during the period of investigation (May 1997 to March 1998) within the sampling stations. Only adult fish were sampled. The specimens were brought to the laboratory and dissected to remove the gills and muscles for analysis. The fish species investigated included: Sardinella gibbosa, Leiognathus equula, Upeneus vittatus, Lutjanus fulviflamma, Sphraena jello, Monodactylus argenteus, Secutor insidiator, 
Mugil mugil, Carangoides gymnostethus, Geres oyena, Crenidens crenidens, Chorinemus tol, Upeneus sulphureus, Siganus sutor, Leptoscarus vaigiensis, Spilotichthys pictus, Upeneus indicus, Upeneus barberinus, Lenthrinus sp. and Therapon jarbu.

In order to obtain representative samples, composites were prepared by taking between four and six of every fish species caught in a given sampling session. The samples were thoroughly homogenised before subjecting them to digestion. The moisture content of the sampled parts for all the fish species analysed was found to range between 73.4 and $76.2 \%$. Digestion of the fish tissues was done according to the procedure described by Giordano et al. (1991). A $5 \mathrm{~g}$ sample (fresh weight) was digested in a quartz Erlenmeyer flask with $12 \mathrm{ml}$ of a mixture of concentrated nitric acid, perchloric acid, and sulphuric acid (25:25 : 1) at $150{ }^{\circ} \mathrm{C}$. Further aliquots of nitric acid were added until a colourless solution was obtained. After evaporation, the residue was dissolved in 10 $\mathrm{ml}$ distilled, deionised water with $1 \mathrm{ml}$ of concentrated hydrochloric acid at $100{ }^{\circ} \mathrm{C}$. Finally, the volume was made up to $50 \mathrm{ml}$ with distilled, deionised water. Blank digestions are treated similarly.

Other associated physical and chemical measurements were carried out according to the methods described in APHA (1995) and Parsons et al. (1984). The parameters included temperature, salinity and dissolved oxygen (DO), which were measured using a mercury thermometer $\left(0-50^{\circ} \mathrm{C}\right)$, a handheld (Atago) refractometer, and the classical Winkler procedure respectively.

\section{Data analysis and quality tests}

Data obtained were subjected to ANOVA to determine spatial and temporal variations. All statistical analyses were based on the significance level at $\mathrm{P}=0.05$ and critical values of $\mathrm{F}$ at $\alpha=$ 0.05 (Yule \& Kendall, 1993). Certified reference material IAEA 140 (Fucus sp. - PhaeophyceaeA 11) was used for analytical assurance of lead and cadmium concentrations. The mean recovery values were $97.2 \%$ for $\mathrm{Pb}$ and $99.7 \%$ for $\mathrm{Cd}$. For the two metals, three parallel analyses of the reference material gave standard deviations of
Table 1. Reagent blanks, coefficients of variation, detection limits and wavelength of detection for lead and cadmium

\begin{tabular}{lcc}
\hline Parameter & $\mathrm{Pb}$ & $\mathrm{Cd}$ \\
\hline Reagent blank (ppm) & $0.015 \pm 0.002$ & $0.006 \pm 0.003$ \\
Coefficient of variation & & \\
$\quad(\%)$ & 2.7 & 3.7 \\
Detection limit (ppm) & $0.1-30$ & $0.02-3.0$ \\
Wavelength (nm) & 217.0 & 228.8 \\
\hline
\end{tabular}

between 0.2 and $2.5 \%$. The mean values for reagent blank, coefficient of variation, detection limits and wavelength of determination for $\mathrm{Pb}$ and $\mathrm{Cd}$ are given in Table 1.

\section{RESULTS AND DISCUSSION}

\section{Physical parameters}

The mean variations in temperature, salinity and dissolved oxygen (DO) in Makupa and Tudor creeks during the wet and dry seasons of the sampling period are shown in Figs 2, 3 and 4 respectively. At Makupa and Tudor creeks, temperature ranged from 27.0-30.5 and 26.5-31.5 ${ }^{\circ} \mathrm{C}$ respectively, salinity from $24.4-35.6$ and 23.4 $35.4 \%$ and dissolved oxygen from 3.9-6.1 and 4.6-7.95 $\mathrm{mg} \mathrm{O}_{2} / 1$. In general, these environmental parameters were not significantly different $(\mathrm{P}>$ 0.05 ) between the two creeks and their seasonal variations were closely related. On average, the salinities were lower in both creeks during the wet season as compared to the dry season (Fig. 3) while the highest values of DO in the two creeks were observed during the wet season (Fig. 4). These observations were probably linked with the vast inflow of freshwater, from surface runoff, during the wet season. Temperatures (Fig. 2) were the least affected by season, though the wet season appeared to be hotter than the dry season in both creeks.

\section{Cadmium}

Cadmium concentration in the water column was below detection limits in all stations sampled, during both seasons (Table 2). In sediment samples, $\mathrm{Cd}$ concentrations ranged from nd to $1.0 \mathrm{mg} / \mathrm{kg}$ dry weight, with a majority of samples lying in 


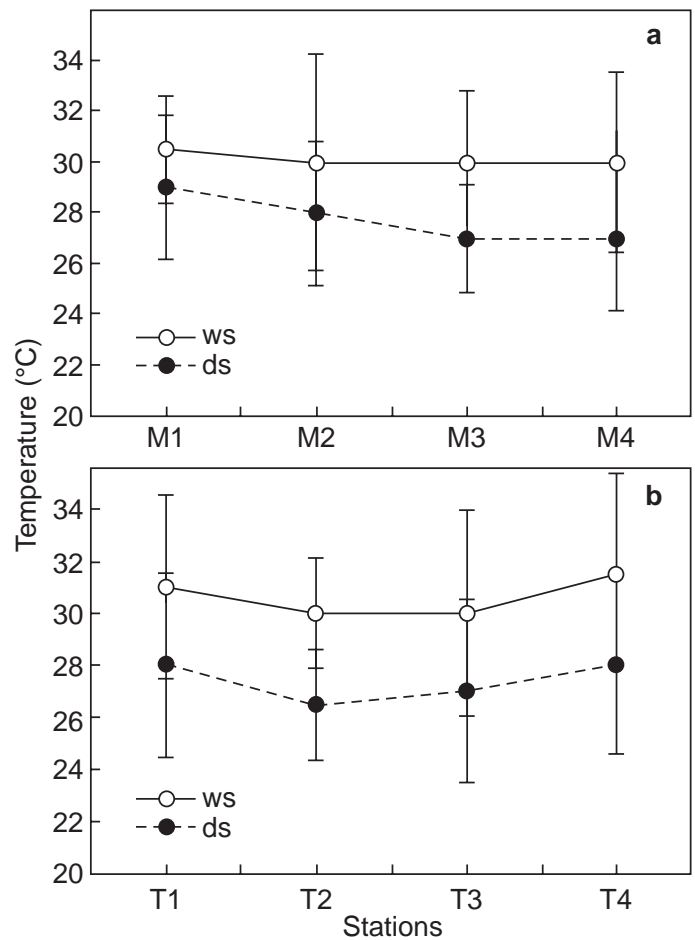

Fig. 2. Mean water column temperature variations in (a) Makupa and (b) Tudor creek during dry (ds) and wet (ws) season

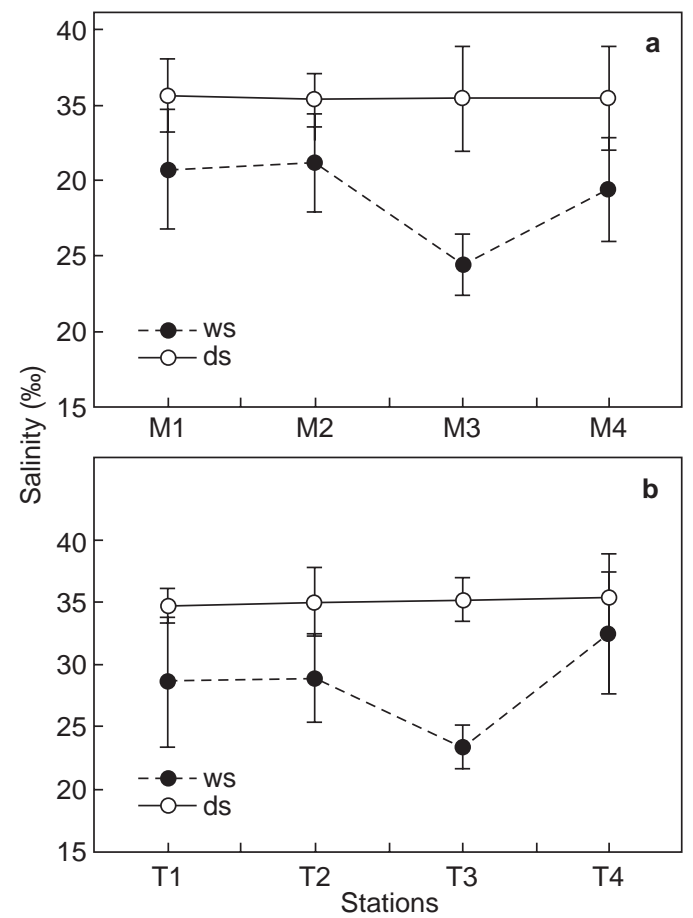

Fig. 3. Mean water column salinity variations in (a) Makupa and (b) Tudor creek during dry (ds) and wet (ws) season

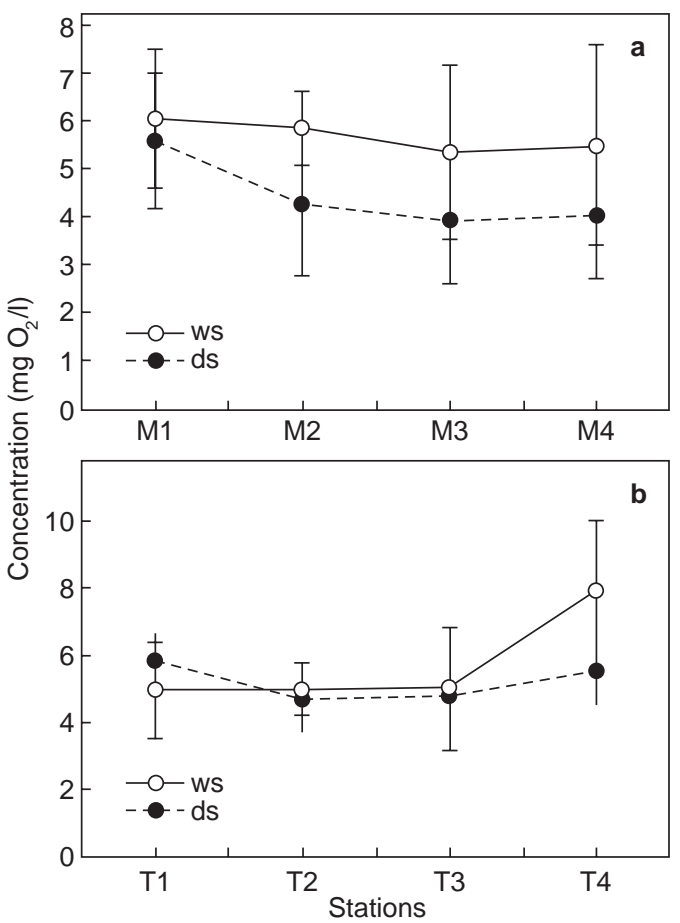

Fig. 4. Mean water column dissolved oxygen (DO) variations in (a) Makupa and (b) Tudor creek during dry (ds) and wet (ws) season

the lower range. The highest value was observed within the Tudor creek next to the Kenya Meat Commission (KMC) beef plant (T1). In both sediments and fish, $\mathrm{Cd}$ concentrations were much lower than the corresponding $\mathrm{Pb}$ concentrations. In the majority of the fish samples, the concentration levels were close to or below the lower detection limit. Apart from a few exceptionally high values found in some fish species caught from areas neighbouring highly anthropogenically influenced localities such as Kibarani dumpsite and KMC (Table 3), the other results are comparable with those obtained in similar studies in the same locality (Kamau, 2001) and elsewhere (Giordano et al., 1991; Lacerda et al., 1992; Mat et al., 1994; Morrisey et al., 1994).

Higher concentrations of $\mathrm{Pb}$ and $\mathrm{Cd}$ were recorded in the gills than in muscle tissues of the fish samples. The highest levels were observed in fish from Makupa creek. The creek also recorded the lowest levels of DO on average, indicating further that this creek is more polluted than the other sampled stations. However, the overall levels 
Table 2. Mean concentrations ( \pm standard deviation) of lead and cadmium in water and sediment for sampled stations in Makupa (M) and Tudor (T) creeks, Mombasa, Kenya during dry and wet seasons. The other stations are comparison stations

\begin{tabular}{|c|c|c|c|c|c|c|c|c|}
\hline \multirow[b]{3}{*}{ Station } & \multicolumn{4}{|c|}{ Water (mg/l) } & \multicolumn{4}{|c|}{ Sediment $(\mathrm{mg} / \mathrm{kg} \mathrm{dw})$} \\
\hline & \multicolumn{2}{|c|}{$\mathrm{Cd}$} & \multicolumn{2}{|c|}{$\mathrm{Pb}$} & \multicolumn{2}{|c|}{$\mathrm{Cd}$} & \multicolumn{2}{|c|}{$\mathrm{Pb}$} \\
\hline & Dry & Wet & Dry & Wet & Dry & Wet & Dry & Wet \\
\hline M1 & nd & nd & nd & $0.001 \pm 0.0002$ & $0.25 \pm 0.35$ & $0.08 \pm 0.01$ & $24.0 \pm 2.8$ & $23.0 \pm 4.2$ \\
\hline M2 & nd & nd & nd & $0.003 \pm 0.0001$ & $0.30 \pm 0.14$ & $0.03 \pm 0.01$ & $26.9 \pm 0.6$ & $33.3 \pm 4.7$ \\
\hline M3 & nd & nd & nd & $0.004 \pm 0.0057$ & $0.25 \pm 0.40$ & $0.025 \pm 0.001$ & $23.5 \pm 0.3$ & $26.3 \pm 0.4$ \\
\hline M4 & nd & nd & nd & $0.005 \pm 0.0071$ & $0.50 \pm 0.01$ & $0.08 \pm 0.001$ & $13.9 \pm 0.1$ & $27.3 \pm 1.8$ \\
\hline $\mathrm{T} 1$ & nd & nd & nd & $0.006 \pm 0.0001$ & $0.25 \pm 0.35$ & $0.025 \pm 0.007$ & $7.6 \pm 0.3$ & $13.5 \pm 1.4$ \\
\hline $\mathrm{T} 2$ & nd & nd & nd & $0.003 \pm 0.0002$ & $1.0 \pm 0.07$ & $0.10 \pm 0.01$ & $11.5 \pm 0.6$ & $17.9 \pm 0.7$ \\
\hline $\mathrm{T} 3$ & nd & nd & nd & $0.001 \pm 0.0001$ & $0.25 \pm 0.01$ & $0.05 \pm 0.028$ & $14.3 \pm 0.3$ & $20.1 \pm 1.3$ \\
\hline $\mathrm{T} 4$ & nd & nd & nd & $0.001 \pm 0.0002$ & $0.75 \pm 0.01$ & $0.13 \pm 0.042$ & $5.9 \pm 0.8$ & $16.8 \pm 1.1$ \\
\hline $\mathrm{CGaB}$ & nd & nd & nd & nd & nd & nd & $1.0 \pm 0.4$ & $2.5 \pm 0.7$ \\
\hline CMkR & nd & nd & nd & nd & nd & nd & $1.3 \pm 0.4$ & $7.8 \pm 1.1$ \\
\hline CKiR & nd & nd & nd & nd & $0.3 \pm 0.02$ & nd & $1.8 \pm 0.3$ & $7.0 \pm 1.4$ \\
\hline $\mathrm{CMiC}$ & nd & nd & nd & $0.005 \pm 0.0002$ & $0.15 \pm 0.01$ & nd & $19.0 \pm 0.7$ & $3.0 \pm 1.4$ \\
\hline CMwR & nd & nd & nd & nd & nd & $0.03 \pm 0.02$ & $20.0 \pm 1.4$ & $9.3 \pm 1.8$ \\
\hline CKoR & nd & nd & nd & nd & $0.25 \pm 0.07$ & $0.28 \pm 0.04$ & $9.0 \pm 1.3$ & $7.5 \pm 1.4$ \\
\hline
\end{tabular}

nd $=$ not detectable.

of $\mathrm{Pb}$ and $\mathrm{Cd}$ observed in this study are comparable to or even lower than those reported previously within the region (Kamau, 2001; Onyari, 1985; Oteko, 1987). While the apparent discrepancy is mainly attributed to the difference in the laboratory analytical procedures used in sample analyses, the exact localities where the samples were collected also needs to be taken into account. Cadmium levels obtained in this study were also found to be lower than those reported in Chilean marine species (Ober et al., 1987). Anthropogenic activities have long been regarded as the main factors associated with elevated heavy metal incidences in the marine environment by various workers elsewhere. Giordano et al. (1991), for example, noted some relatively high metal concentrations especially in mussels found in localities, such as harbours, with intensive anthropogenic activities.

Overall, no statistically significant correlations were found between the $\mathrm{Pb}$ and $\mathrm{Cd}$ concentrations at the various sites. However, the few samples found with elevated concentrations of these metals can be associated with localities characterised by intensive anthropogenic activities, i.e. the Kibarani municipal garbage dumpsite, the Mombasa port (Makupa Creek) and the beef factory, KMC (Tudor
Creek). Other more diffuse effluent sources also to be taken into account include untreated sewage outflow, surface runoff during stormy spells (wet season) and the two seasonal rivers, viz. Mwache and Kombeni, which drain into the Port Reitz and Tudor creeks at the western and northern ends of the study area respectively.

With a few exceptions, the fish examined in this study had $\mathrm{Pb}$ and $\mathrm{Cd}$ concentrations within allowable levels, based on the food regulatory standards proposed by FAO (1983) and Ober et al. (1987).

\section{Lead}

Mean lead concentration ranged from not detectable (nd) to $0.005 \mathrm{mg} / \mathrm{l}$ in the water samples (Table 2), with concentrations being detectable mainly during the wet season. The upper limit for $\mathrm{Pb}$ in water $(0.012 \mathrm{mg} / \mathrm{l})$ was obtained in one of the water samples in the sample batch for wet season in Makupa Creek. There was, however, no significant variation $(\mathrm{P}>0.05)$ between these values with respect to the stations of Makupa and Tudor creeks. The $\mathrm{Pb}$ concentrations in the comparison stations were undetectable except at CMiC. 
Table 3. Mean lead and cadmium concentrations ( \pm standard deviation) for fish sampled during dry and wet seasons in Makupa and Tudor creeks, Mombasa, Kenya

\begin{tabular}{|c|c|c|c|c|c|c|c|c|}
\hline \multirow[b]{2}{*}{ Season } & \multirow{2}{*}{$\begin{array}{l}\text { Sampling } \\
\text { station }\end{array}$} & \multirow{2}{*}{$\begin{array}{l}\text { Fish } \\
\text { species }\end{array}$} & \multicolumn{3}{|c|}{$\mathrm{Cd}$} & \multicolumn{3}{|c|}{$\mathrm{Pb}$} \\
\hline & & & Muss & & Gill & Muscle & Gill & \\
\hline \multirow[t]{21}{*}{ Dry season } & \multirow[t]{4}{*}{ Makupa } & Sphraena jello & & nd & $0.36 \pm 0.09$ & nd & $2.86=$ & \pm 0.08 \\
\hline & & Monodactylus argenteus & 0.2 & \pm 0.01 & $1.25 \pm 0.35$ & $1.6 \pm 0.28$ & $7.5=$ & \pm 0.71 \\
\hline & & Leiognathus equula & 0.2 & \pm 0.07 & $0.83 \pm 0.04$ & $1.4 \pm 0.30$ & $5.0=$ & \pm 2.83 \\
\hline & & Secutor insidiator & 0.2 & \pm 0.03 & $2.5 \pm 0.71$ & $1.2 \pm 0.57$ & $12.5=$ & \pm 1.41 \\
\hline & \multirow[t]{7}{*}{ Tudor creek } & Chorinemus tol & 0.4 & \pm 0.28 & $0.2 \pm 0.13$ & $2.2 \pm 0.28$ & $1.8=$ & \pm 0.42 \\
\hline & & Carangoides gymnostethus & 0.2 & \pm 0.14 & $0.2 \pm 0.01$ & $1.6 \pm 0.14$ & 1.8 & \pm 0.71 \\
\hline & & Sardinella gibbosa & 0.2 & \pm 0.10 & $0.6 \pm 0.35$ & $1.0 \pm 0.71$ & 2.6 & \pm 0.85 \\
\hline & & Geres oyena & & nd & $0.6 \pm 0.21$ & $1.0 \pm 0.42$ & $2.4=$ & \pm 0.28 \\
\hline & & Crenidens crenidens & 0.2 & \pm 0.11 & $0.6 \pm 0.07$ & $1.4 \pm 0.85$ & $2.6=$ & \pm 0.30 \\
\hline & & Chorinemus tol & 0.2 & \pm 0.04 & nd & $2.0 \pm 1.20$ & $2.7=$ & \pm 0.85 \\
\hline & & Upeneus sulphureus & 0.4 & \pm 0.14 & nd & $2.0 \pm 0.78$ & $3.5=$ & \pm 0.42 \\
\hline & \multirow[t]{6}{*}{ Gazi bay } & Leptoscarus vaigiensis & 0.2 & \pm 0.16 & $0.29 \pm 0.06$ & $1.0 \pm 0.55$ & $2.7=$ & \pm 0.99 \\
\hline & & Crenidens crenidens & & nd & $0.71 \pm 0.08$ & $0.4 \pm 0.17$ & $4.3=$ & \pm 0.57 \\
\hline & & Upeneus barberinus & & nd & nd & $1.2 \pm 0.42$ & 4.2 & \pm 1.13 \\
\hline & & Lutjanus fulviflamma & 0.2 & \pm 0.08 & $0.42 \pm 0.06$ & $2.0 \pm 1.77$ & $3.3=$ & \pm 0.57 \\
\hline & & Lenthrinus sp. & 0.2 & \pm 0.03 & $0.42 \pm 0.10$ & $1.0 \pm 0.76$ & $2.5=$ & \pm 0.48 \\
\hline & & Siganus sutor & 0.2 & \pm 0.02 & $0.83 \pm 0.42$ & $1.0 \pm 0.31$ & $4.2=$ & \pm 0.48 \\
\hline & \multirow[t]{4}{*}{ Mida creek } & Leptoscarus vaigiensis & 0.06 & \pm 0.03 & $0.08 \pm 0.03$ & $0.8 \pm 0.47$ & $3.2=$ & \pm 0.28 \\
\hline & & Siganus sutor & 0.04 & \pm 0.03 & $0.41 \pm 0.03$ & $0.4 \pm 0.38$ & $3.72=$ & \pm 0.31 \\
\hline & & Therapon jarbu & 0.04 & \pm 0.01 & $0.13 \pm 0.04$ & $0.6 \pm 0.06$ & $4.08=$ & \pm 1.53 \\
\hline & & Upeneus sulphureus & 0.08 & \pm 0.06 & $0.32 \pm 0.04$ & $3.8 \pm 0.42$ & $5.81=$ & \pm 1.15 \\
\hline \multirow[t]{13}{*}{ Wet season } & \multirow[t]{4}{*}{ Makupa } & Sardinella gibbosa & 0.34 & \pm 0.09 & $2.25 \pm 0.35$ & $4.8 \pm 1.13$ & $17.9=$ & \pm 2.6 \\
\hline & & Leiognathus equula & & nd & nd & $3.6 \pm 0.35$ & $24.9=$ & \pm 2.7 \\
\hline & & Upeneus vittatus & & nd & nd & $6.0 \pm 1.1$ & $22.3=$ & \pm 1.8 \\
\hline & & Lutjanus fulviflamma & & nd & nd & $5.0 \pm 1.3$ & $58.3=$ & \pm 1.4 \\
\hline & \multirow[t]{4}{*}{ Tudor creek } & Sardinella gibbosa & 3.4 & \pm 0.71 & $3.5 \pm 1.41$ & $3.8 \pm 0.42$ & $6.6=$ & \pm 1.7 \\
\hline & & Leiognathus equula & 0.76 & \pm 0.09 & $3.7 \pm 1.00$ & $18.5 \pm 3.54$ & $17.6=$ & \pm 3.7 \\
\hline & & Lutjanus fulviflamma & 0.54 & \pm 0.09 & $0.64 \pm 0.20$ & $5.0 \pm 2.3$ & $9.0=$ & \pm 4.7 \\
\hline & & Mugil mugil & 0.1 & \pm 0.10 & $0.43 \pm 0.04$ & $5.0 \pm 0.42$ & $5.0=$ & \pm 0.9 \\
\hline & \multirow[t]{5}{*}{ Gazi bay } & Siganus sutor & 0.07 & \pm 0.04 & $0.09 \pm 0.01$ & $6.0 \pm 0.4$ & $5.6=$ & \pm 0.7 \\
\hline & & Leptoscarus vaigiensis & 0.09 & \pm 0.06 & $0.09 \pm 0.04$ & $5.8 \pm 1.0$ & $5.2=$ & \pm 0.5 \\
\hline & & Spilotichthys pictus & 0.15 & \pm 0.11 & $0.05 \pm 0.03$ & $4.8 \pm 0.3$ & $6.2=$ & \pm 0.3 \\
\hline & & Upeneus indicus & 0.07 & \pm 0.06 & $0.07 \pm 0.01$ & $3.6 \pm 0.1$ & $11.2=$ & \pm 3.1 \\
\hline & & Sphraena jello & 0.09 & \pm 0.03 & $0.11 \pm 0.04$ & $5.2 \pm 0.4$ & $9.8=$ & \pm 0.4 \\
\hline
\end{tabular}

nd $=$ not detectable

Sediments, on the other hand, were found to have $\mathrm{Pb}$ concentrations ranging from 0.2 to 58.0 $\mathrm{mg} / \mathrm{kg}$ dry weight, with the highest values being observed in the Makupa creek and the lowest at the Gazi Bay station $(\mathrm{CGaB})$, the latter of which is known to have a relatively pristine environment according to previous studies (Mwashote, 1997; Ohowa et al., 1997). The overall mean range of $\mathrm{Pb}$ concentration in sediments was 1.0 to $33.3 \mathrm{mg} / \mathrm{kg}$ (Table 2). Analysis of variance showed no significant variation $(\mathrm{P}>0.05)$ in the levels of the two metals during the wet and dry seasons, either within or between Makupa and Tudor creeks.

Lead concentrations in the fish samples ranged from nd to 18.5 and nd to $58.3 \mathrm{mg} / \mathrm{kg}$ wet weight, for muscle and gill tissues respectively (Table 3 ). 
Fish species caught in the Makupa and Tudor creeks showed higher values. However, there was no discernible spatial variation $(\mathrm{P}>0.05)$ in $\mathrm{Pb}$ concentrations in water and sediments in the creeks. Furthermore, $\mathrm{Pb}$ levels were no higher nearer Kilindini port, Kibarani dumpsite or the KMC meat factory. However, overall levels of $\mathrm{Pb}$ amongst the stations in the two creeks were higher than those in the stations outside the creeks (Table 2). In areas with elevated $\mathrm{Pb}$ concentrations in the water and sediment samples, corresponding observations were made of $\mathrm{Pb}$ levels in fish. In addition, elevated $\mathrm{Pb}$ levels were commonest during the wet season as compared to the dry season.

In the marine environment, there are various factors involved in the metal leaching into the water (Waldichuk, 1985). Some of the most important factors include the natural processes releasing metals from minerals, physical characteristics of sediments, biogeochemical processes in the sediments, mine tailings, sewage sludge and dredge spoils and effects of water characteristics (temperature, salinity, $\mathrm{pH}$ and DO).

\section{CONCLUSION AND RECOMMENDATIONS}

The uptake modes of heavy metals by marine organisms, which may be through food or water, need to be investigated. Studies on some invertebrates (Uthe \& Zitko, 1980) show that equal amounts can be taken in through either route. Giordano et al. (1991), showed that the fish species Serranus scriba exhibited a significantly higher ability to concentrate mercury (mean concentration $316 \pm 54 \mu \mathrm{g} / \mathrm{kg}$ fresh wt.) than $S$. cabrilla (mean concentration $181 \pm 86 \mu \mathrm{g} / \mathrm{kg}$ fresh wt.). The differences between these species were attributed to their behaviour and habitats. In addition, in some species there may be a difference between males and females in rate of uptake and release of metals. The specific organ and the age of an animal also influence their retention capacities of the metals (Goldberg, 1980).

The major contaminant inputs and sediment contaminant impacts occur on nearshore coastal systems (Scott, 1989). In their review of stress effects on benthic communities, Boesch \& Rodenburg (1981) suggest that nearshore organisms, especially those in estuarine localities, are more resistant than are those in more stable environments (such as the deep sea) to environmental stresses, including variable salinity, temperature and suspended solids. However, the variable recruitment and distribution patterns of these nearshore species make it difficult to understand contaminant effects, and their long-term costs to the organism. The significance of bioaccumulation and transfer of contaminants in the food chain is also poorly understood.

The effects of long-term stress on marine organisms, especially fish, and their ability to adapt to chronic stress of heavy metal pollutants, is a critical factor in the management of point and nonpoint source discharges. There is therefore a need for the development of laboratory test systems to evaluate chronic stress. Efforts should concentrate on chronic level effects and on bioaccumulation studies. The methods should have the ability to predict such effects under field conditions and be able to predict between lower and higher levels of biological organisation.

In light of the foregoing, it is clear that further studies on heavy metals are required within the Makupa and Tudor creeks as well as the rest of the Kenya coastal marine environment. Such studies should take into consideration the various aspects mentioned above, and importantly, should aim to quantify the biologically available heavy metals, and understand how bioaccumulation of a metal is related to the specific fish species, age, feeding habit and locality, and how all these factors interrelate at the spatial and temporal scales. This will help shed light on the long-term, low-level contaminant input to coastal systems and the resultant changes in species composition and abundance. Given our inability at the present time to discriminate between contaminant effects and natural variability, these types of changes are often confused.

It is recommended that a stricter policy aimed at curbing the disposal of refuse associated with heavy metals into the marine environment should be instituted and enforced by the authorities responsible.

Acknowledgements - I wish to express my sincere gratitude to WIOMSA for financial assistance through the IOC/UNESCO MARG I contract no. SC-298.153.7. I also thank N. Mzigo, J. Gonda, J. 
Kamau, B. Orembo, R. Anam, C. Gaya, P. Omondi, J. Ayoyi, P. Chiteri, J. Bonyi and P. Githui, for their skilled and untiring work both in the field and laboratory. I would also like to thank the scientific and administrative staff of KMFRI who contributed either directly or indirectly to the success of this work. P. Bor of Mines and Geology department, Nairobi is much acknowledged for availing the AAS for the sample analyses.

\section{REFERENCES}

APHA (1995) Standard methods for the examination of water and waste water, 19th edition. American Public Health Association et al., New York, USA.

Boesch, D.F and Rosenberg, R. (1981) Response to stress in marine bethic communities. In: Barret, G. W. and Rosenberg, R. (eds) Stress effects in natural systems. John Wiley and Sons, New York. pp. 70-77.

Brewer, P. G., Spencer, D.W. and Smith, C. L. (1969) Determination of trace metals in seawater by atomic absorption spectrophotometry. Atomic Absorption Spectroscopy, ASTM STP 443, American Society for Testing and Materials. pp.70-77.

Bryan, G.W. (1976) Some effects of heavy metal tolerance in aquatic organisms. In: Lockwood A.P.M. (ed.) Effects of pollutants on aquatic organisms. Cambridge University Press. Cambridge, England. pp. 7-34.

FAO (1975) Manual of methods in aquatic environment research: Part 1 -methods for detection, measurement and monitoring of water pollution. FAO Fisheries Technical paper no. 137. FIRI/T137. pp. 211-218.

FAO (1983) Fisheries circular no. 764: Compilation of legal limits for hazardous substances in fish and fishery products. FAO, Rome.

Forstner, U. (1990) Contaminated sediments. Lecture Notes in Earth Science, 21. Springer-Verlag, Berlin. 157 pp.

Giordano, R., Arata, P., Ciaralli, L., Rinaldi, S., Giani, M., Cicero, M.A. and Costantini, S. (1991) Heavy metals in mussels and fish from Italian coastal waters. Mar. Poll. Bull. 22: 10-14.

Golberg, E.D. (1980) The international mussel watch. National Academy of Sciences, Washington DC.

GoK (1988) Tourist market report 1987/1988. Ministry of Tourism and Wildlife, Kenya.

Jenne, E.A. and Luoma, S.N. (1977) Forms of trace elements in soils, sediments and waters: An overview of their determination and biological availability. In: Biological implications of metals in the environment. ERDA Ser. No. 42.
Washington, DC. pp. 110-143.

Kamau, J. N. (2001) Heavy metals distribution in sediments along the Kilindini and Makupa creeks, Kenya. Hydrobiologia 458: 235-240.

Kim, G., Yang, H.-S. \& Kodama, Y. (1998) Distributions of transition elements in the surface sediments of the Yellow Sea. Continental Shelf Research 18: 1531-1542.

Lacerda, L. D. (1990) Metal biogeochemistry in coastal lagoons. In: Kjerfve B. (eds) Coastal lagoons processes. Elsevier Science, Amsterdam. 577 pp.

Lacerda, L. D., Fernandez, M. A., Calazans, C. F. and Tanizaki, K. F. (1992) Bioavailability of heavy metals in sediments of two coastal lagoons in Rio de Janeiro, Brazil. Hydrobiologia 228: 65-70.

Lacerda, L.D., Martinelli, L.A., Rosende, C.E., Mozetto, A.R.C., Ovalle, R.L., Victoria, S., Silva, C. A. R. \& Noguera, F.B. (1988) The fate of trace metals in suspended matter in a mangrove creek during a tidal cycle. Sci. Tot. Environ. 75: 249-259.

Mat, I., Maah, M. J. \& Johari, A. (1994) Trace metal geochemical associations in sediments from the culture-bed of Anadara granosa. Mar. Poll. Bul. 28: 319-323.

McConchie, D. M., Mann, A. W., Lintern, M. J., Longman, D., Gabelish, A. J. \& Gabelish, M. J. (1988) Heavy metals in marine biota, sediments and waters from the Shark bay area, Western Australia: J. Coast. Res. 4: 37-58.

Mohan, P. M. (1997) Trace element geochemistry of modern sediments of the Vellar River and its surrounding environments. Indian J. Mar. Sci. 26: 150-157.

Morrisey, D. J., Stark, J. S., Howitt, L. \& Underwood, A. J. (1994) Spatial variation in concentrations of heavy metals in marine sediments. Aust. J. Freshwater Res. 45: 177-184.

Mwashote, B. M. (1997) Sources of dissolved inorganic nutrient fluxes in the Gazi bay and implications for coastal ecosystems. MSc Thesis, University of Nairobi, Kenya. 114 pp.

Ober, G. A., Gonzalez, M. \& Maria, I. S. (1987) Heavy metals in molluscan, crustacean and other commercially important Chilean marine coastal waters species. Bull. Environ. Contam. Toxicol. 38: 534-539.

Ohowa, B. O., Mwashote, B. M. \& Shimbira, W. S. (1997) Dissolved inorganic nutrient fluxes from two seasonal rivers into Gazi bay, Kenya. Est. Coast. Shelf Sci. 45: 189-195.

Onyari, J. M. (1985) Determination of manganese, iron copper, zinc, cadmium and lead in fish species and sediments from Mombasa town and Winam Gulf of Lake Victoria. MSc Thesis, University of Nairobi, Kenya. 282 pp. 
Oteko, D. (1987) Analysis of some major trace metals in the sediments of Gazi bay, Makupa, and Tudor creeks of the Kenyan coast: A comparative investigation into the anthropogenic input levels. MSc Thesis, Vrije Universiteit, Brussel. 190 pp.

Parsons, T. R., Maita, Y. \& Lalli, C. M. (1984) A manual of chemical and biological methods for seawater analysis. Pergamon Press, Oxford England. 173 pp.

Peerzada, N. \& Rohoza, W. (1989) Some heavy metals in sediments from Darwin harbour, Australia. Mar. Poll. Bull. 20: 91-92.

Scott, K. J. (1989) Effects of contaminated marine sediments-assessment and remediation. (ed.) Committee on contaminated marine sediments. pp. 132-154.
Souza, C. M. M., Pestana, M. H. D. \& Lacerda, L. D. (1986) Geochemical partitioning of heavy metals in the sediments of three coastal lagoons along the Rio de Janeiro coast (Brazil). Sci. Tot. Environ. 58: $63-72$.

Uthe, J. F. \& Zitko, V. (1980) Cadmium pollution of Nelledune Harbour, New Brunswick, Canada. Can. Tech. Rept. Fish. Aquat. Sci. 963.

Waldichuk, M. (1985) Biological availability of metals to marine organisms. Mar. Poll. Bull. 16: 7-11.

Watling, H. R. (1983) Accumulation of seven metals by Crassostrea gigas, C. margaritacea, Perna perna and Chloromytilus meridionalis. Bull. Environ. Contam. Toxicol. 30: 213-320.

Yule, G. U. \& Kendall, M. G. (1993). An introduction to the theory of statistics. Edward Arnold, England. $701 \mathrm{pp}$. 